\title{
Fine mapping of a quantitative resistance gene for gray leaf spot of maize (Zea mays L.) derived from teosinte (Z. mays ssp. parviglumis)
}

\author{
Xinye Zhang ${ }^{1,2} \cdot$ Qin Yang $^{2} \cdot$ Elizabeth Rucker ${ }^{3} \cdot$ Wade Thomason $^{3} \cdot$ \\ Peter Balint-Kurti ${ }^{2,4}$
}

Received: 4 January 2017 / Accepted: 27 February 2017 / Published online: 24 March 2017

(C) Springer-Verlag Berlin Heidelberg (outside the USA) 2017

\begin{abstract}
Key message In this study we mapped the QTL Qgls8 for gray leaf spot (GLS) resistance in maize to a $\sim 130 \mathrm{~kb}$ region on chromosome 8 including five predicted genes. Abstract In previous work, using near isogenic line (NIL) populations in which segments of the teosinte (Zea mays ssp. parviglumis) genome had been introgressed into the background of the maize line B73, we had identified a QTL on chromosome 8 , here called $Q g l s 8$, for gray leaf spot (GLS) resistance. We identified alternate teosinte alleles at this QTL, one conferring increased GLS resistance and one increased susceptibility relative to the B73 allele. Using segregating populations derived from NIL parents carrying
\end{abstract}

Communicated by Mingliang Xu.

Xinye Zhang and Qin Yang have contributed equally to the work.

Electronic supplementary material The online version of this article (doi:10.1007/s00122-017-2888-2) contains supplementary material, which is available to authorized users.

Peter Balint-Kurti

Peter.Balint-Kurti@ars.usda.gov

Qin Yang

qyang6@ncsu.edu

1 Maize Research Institute, Sichuan Agricultural University, 211 Huimin Road, Wenjiang District, Chengdu, Sichuan 611130, China

2 Department of Entomology and Plant Pathology, North Carolina State University, Raleigh, NC 27695, USA

3 Department of Crop and Soil Environmental Sciences, Virginia Tech, Blacksburg, VA 24061, USA

4 U.S. Department of Agriculture, Agricultural Research Service (USDA-ARS) Plant Science Research Unit, Raleigh, NC, USA these contrasting alleles, we were able to delimit the QTL region to a $\sim 130 \mathrm{~kb}$ (based on the B73 genome) which encompassed five predicted genes.

\section{Introduction}

Gray leaf spot (GLS) is a major foliar disease of maize, caused by the fungal pathogens Cercospora zeae-maydis and Cercospora zeina (Crous et al. 2006; Meisel et al. 2009; Korsman et al. 2012). The disease was first reported in Illinois (USA) (Tehon and Daniels 1925) and occurs in many maize-growing countries (Ward et al. 1999; Okori et al. 2004; Juliatti et al. 2009; Meisel et al. 2009; Kinyua et al. 2010; Manandhar et al. 2011; Liu and Xu 2013; Nega et al. 2016). The fungus can overwinter in the debris of diseased corn plants left on the soil surface and conidia produced in the following spring can be spread by wind or rain splashing. High relative humidity and prolonged periods of leaf wetness are ideal conditions for GLS epidemics (Rupe et al. 1982; Lipps 1998; Clements et al. 2000; Zhang et al. 2012; Dhami et al. 2015). GLS lesions are usually first observed on the lower leaves and then spread up the plant during the season. Yield losses are generally due to reduction in photosynthetic leaf area (Lipps 1998; Ward et al. 1999; Zhang et al. 2012). Compared with other methods, such as reduced conservation tillage, crop rotation, and the application of fungicides, improvement of host resistance is accepted as the most economical and environmentally friendly method for controlling GLS (Lehmensiek et al. 2001).

Resistance to GLS is quantitatively inherited, and quantitative trait loci (QTL) for GLS resistance have been identified on all 10 chromosomes of maize across different mapping populations (Bubeck et al. 1993; 
Saghai Maroof et al. 1996; Clements et al. 2000; Lehmensiek et al. 2001; Gordon et al. 2004; Danson et al. 2008; Balint-Kurti et al. 2008; Pozar et al. 2009; Zwonitzer et al. 2010; Asea et al. 2012; Chung et al. 2011; Veiga et al. 2012; Zhang et al. 2012; Berger et al. 2014; Benson et al. 2015). In meta-analyses, Shi et al. (2007) identified seven consensus GLS resistance QTLs in bins 1.06, 2.06, 3.04, 4.06, 4.08, 5.03, and 8.06 (Davis et al. 1999), and Yan et al. (2016) confirmed 13 consensus QTLs including major QTL on chromosomes 1 and 4.

The narrow genetic basis of cultivated maize is an important factor limiting the breeding of new maize varieties for high-yield and disease resistance (Wallace et al. 2014). The genus Zea consists of five species divided into two sections; Section Luxuriantes including the species Z. diploperennis, Z. perennis, Z. luxurians, and $Z$. nicaraguensis and Section Zea, which includes only one species, Zea mays. Zea mays is further categorized into 4 subspecies one of which is modern maize (Zea mays ssp. mays). Another subspecies, Z. mays ssp. parviglumis is thought to be the immediate ancestor of cultivated maize (Matsuoka et al. 2002). The term teosinte is often used to describe all the species and subspecies within genus Zea that are not cultivated maize (Doebley and Iltis 1980; Iltis and Doebley 1980).

It has been proposed that teosintes can be used as genetic resources for the improvement of modern maize through the introduction of pre-domestication alleles (Liu et al. 2016); however, the substantial anatomical differences between teosintes and cultivated maize limit their use in breeding programs. Liu et al. (2016) developed a set of 928 near isogenic lines in which genomic fragments from 10 different $Z$. mays ssp. parviglumis accessions were introgressed in the background of the maize inbred B73. Lennon et al. (2016) screened this population for GLS resistance and identified and validated several alleles derived from teosinte which conferred GLS resistance. In one case, alternate alleles were identified from different teosinte accessions at a QTL in bin 8.06, one of which conferred GLS resistance and the other susceptibility with respect to the corresponding B73 allele. We reasoned that if these alleles were segregating against each other in a mapping population, the contrast between resistant and susceptible individuals would be enhanced and the locus would be easier to finemap than the other QTL we identified. In this study, we constructed such populations in a B73 NIL background and used them to map the QTL, which we refer to here as $Q g l s 8$, to an interval of $\sim 130 \mathrm{~kb}$.

\section{Materials and methods}

\section{Plant materials}

In our previous study (Lennon et al. 2016), a previously developed population of teosinte/B73 NILs (Liu et al. 2016) was screened for resistance to GLS, and a pair of maize-teosinte (Zea mays ssp. parviglumis) B73 NILsZ032E0081 and Z033E0056 were identified, which both harbored teosinte introgressions at the QTL region in Bin 8.06 (Fig. 1). The alleles from Z032E0081 and Z033E0056, respectively, increased and decreased GLS resistance compared with the allele from the recurrent parent, the maize inbred line B73. In this study, $F_{2: 3}$ and $F_{4}$ populations developed from crosses between these two lines were used in the validation and fine mapping of this QTL which was named $Q g l s 8$ (Fig. 2).

\section{Field trials and disease scoring}

Seventy-four recombinant $F_{2: 3}$ families were planted in Andrews (North Carolina) and at Kentland Research Farm, Blacksburg (Virginia) as one replication in each location in the summer of 2015. In summer of 2016, 142 homozygous recombinant $F_{4}$ lines were planted in Andrews and Blacksburg using a randomized complete block design with two replicates in each environment. In all trials, 15 seeds of each $F_{2: 3}$ family or $F_{4}$ line were planted in each row. The length of each row was $4 \mathrm{~m}$, and the width between rows was $1 \mathrm{~m}$.

Andrews is an ideal environment for GLS resistance identification because of the favorable epidemic conditions for GLS (the morning mists and dews and moderate temperatures). In addition, there are sufficient sources

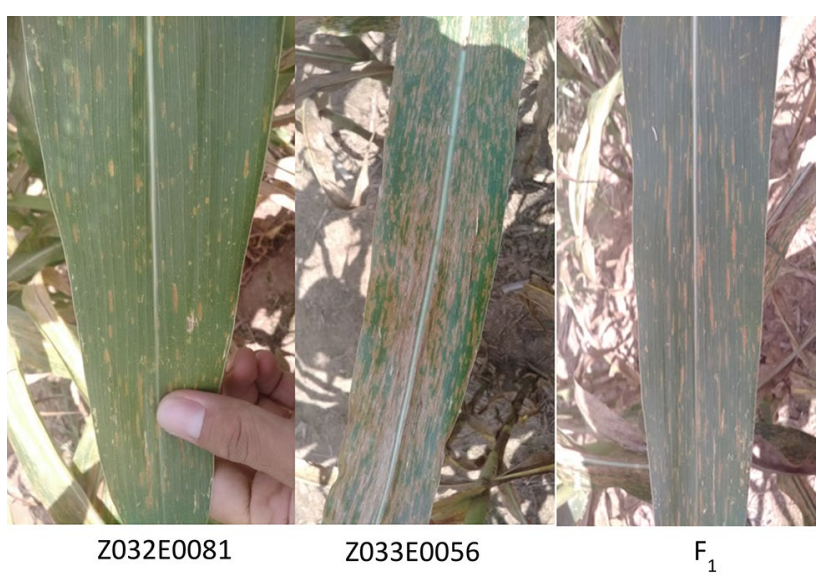

Fig. 1 The field performance of Z032E0081 and Z033E0056 and their $F_{1}$. Pictures were taken of the ear leaves of plants in neighboring rows on the same day in Andrews, NC 
1273 Z033E0056/Z032E0081 $\mathrm{F}_{2}$ plants,

genotyped and selfed (summer 2014 and 2015)

Marker selected

(PZA03612-2; umc1287)

$279 F_{2}$ plants from which were derived $279 F_{2: 3}$ recombinant families
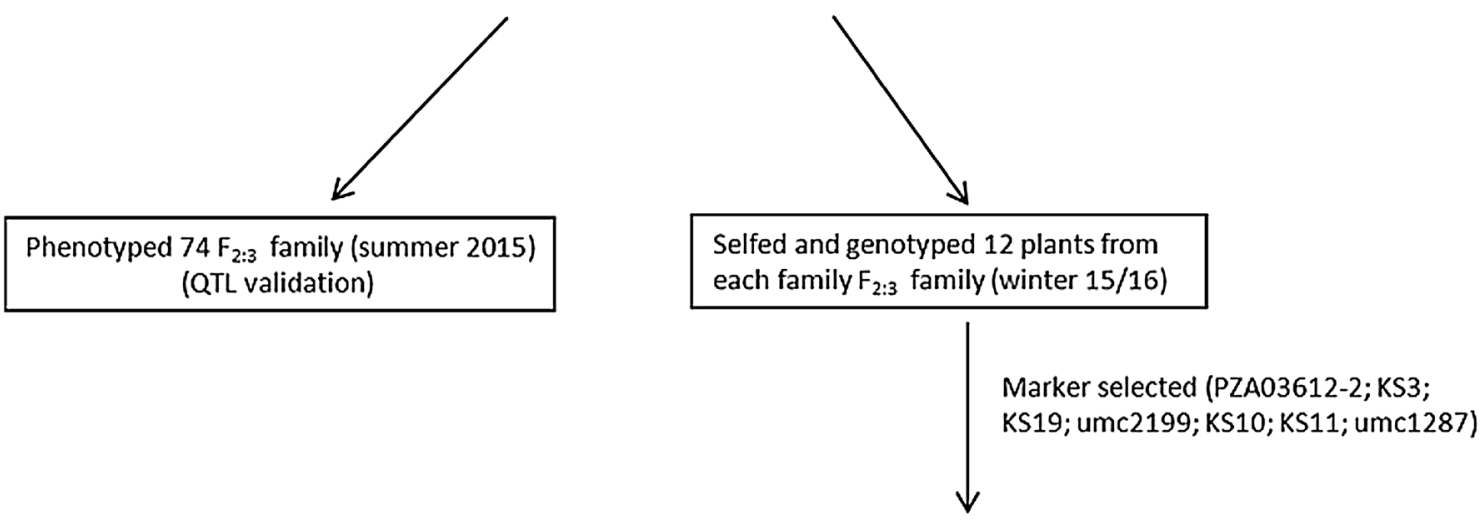

142 independently-derived homozygous recombinants identified

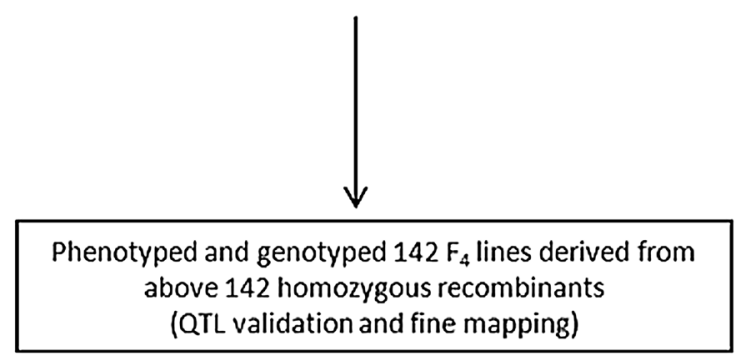

Fig. 2 The scheme used for fine mapping $Q g l s 8$

of inoculum left on the field surface from previous year (Balint-Kurti et al. 2008; Lennon et al. 2016), so GLS can occur naturally with inoculation. In Blacksburg, all the materials were inoculated artificially 30-45 days after planting with sorghum seeds infested by several isolates of Cercospora zeae-maydis. In each environment, disease scoring was performed two times with 10 days interval, starting $\sim 2$ weeks after anthesis. The scales used for GLS rating were from 1 to 9 , where 1 means a completely dead plant and 9 represents no evidence of disease (Lennon et al. 2016). The average GLS score of each row was calculated.

The infested sorghum seeds were prepared in the following way: The seeds were soaked in water over 2-3 days and autoclaved in $1 \mathrm{~L}$ Erlenmeyer flasks. Cercospora zeae-maydis was grown on V8 agar plates for about 2 weeks at room temperature. Mycelia were macerated in water under sterile conditions and $5 \mathrm{ml}$ of this mixture was added to each flask. The fungus was grown in the flask for about 4 weeks, until the seeds were visibly heavily infested. The infested seeds were then dried using simple fans in an open (non-sterile) space. The dried infested seed were used as inoculum.

\section{DNA extraction}

All DNA extraction was performed using 96-well plate (Stripes of 8 Attached $1.1 \mathrm{ml}$ Micro Tubes ${ }^{\mathrm{TM}}$ in Convenient BulkPacks ${ }^{\mathrm{TM}}$, National Scientific Supply Co, Inc. Reorder\#: TN0946-08B). For each sample, about $100 \mathrm{mg}$ leaf tissue was frozen and ground with a stainless steel ball using a shaker (Retsch, Inc.). $500 \mu \mathrm{l}$ of SDS buffer was added into each sample (500 $\mathrm{ml}$ SDS buffer contains $14.6 \mathrm{~g}$ $\mathrm{NaCl}, 9.3 \mathrm{~g}$ EDTA-2Na, $50 \mathrm{ml} 1 \mathrm{M} \mathrm{pH} 8.0$ Tris-HCl, $7.5 \mathrm{~g}$ SDS). The 96 -well plate carrying mixtures of leaf tissues and SDS buffer was incubated in $65^{\circ} \mathrm{C}$ water bath about $30 \mathrm{~min}$. $450 \mu \mathrm{l}$ Tris-Phenol/ $\mathrm{CHCl}_{3}$ (1:1) was added into each sample, mixed and the 96-well plate was spun at $3800 \mathrm{rpm}$ for $10 \mathrm{~min}$. The upper aqueous was transferred into another new 96-well plate. 0.7 volume of isopropanol was added, mixed, and the plate was spun at $3800 \mathrm{rpm}$ for 
$10 \mathrm{~min}$. The supernatant was removed and the DNA pellet was washed with $100 \mu \mathrm{l} 70 \%$ ethanol. The plate was centrifuged at $3800 \mathrm{rpm}$ for $5 \mathrm{~min}$. The supernatant was discarded and the DNA allowed to dry for $\sim 30 \mathrm{~min}$. The dried DNA was suspended in $50 \mu$ sterile TE solution $(10 \mathrm{mM}$ Tris-HCl, 1 mM EDTA, pH 8.0).

\section{Development and scoring of molecular markers}

We developed 14 novel SNP/InDel assays for this work (Table 1). The B73 reference genomic sequence in the QTL region (from PZA03612-2 to umc1287) was used to design PCR primers to amplify $\sim 500-1000$ bp regions at $\sim 1 \mathrm{cM}$ intervals from the two parents. In some cases, the PCR primers used were derived from a previous paper (Chung et al. 2010). PCR products were cleaned using QIAquick ${ }^{\circledR}$ Gel Extraction Kit (Cat\# 28704). All these products were sequenced at the Genomic Sciences Laboratory (North Carolina State University), and the sequences of Z033E0056 and Z032E0081 were aligned to identify single-nucleotide polymorphisms (SNPs) or insertion-deletion (InDel) polymorphisms. If a SNP or InDel polymorphism was identified, the context sequence was provided to LGC Genomics LLC (Beverly, MA, USA) in order to design a "Kompetitive Allele Specific PCR" (KASP) assay (He et al. 2014) that could be used to genotype plants at the corresponding locus. Information on the SNPs and the primers used for the KASP assays is listed in Table 1. KASP primers designed using sequences of PCR products amplified with primers from Chung et al. (2010) have a "ctg" prefix, while others have a "KS" prefix. Markers PZA03612-2 and PZA00429-1 were derived from our previous study (Lennon et al. 2016).

In addition to the markers that were scored by KASP assays, three other classes of markers were used. Three previously characterized SSR markers (http:// www.maizegdb.org/) were used (umc2199, umc2210, umc1287-Table 2). These SSR markers were genotyped

Table 1 SNP/InDel marker information

\begin{tabular}{|c|c|c|c|c|c|}
\hline Primer name & $\begin{array}{l}\text { Position (v3) } \\
(\mathrm{bp})^{\mathrm{a}}\end{array}$ & Allele $\mathrm{FAM}^{\mathrm{b}}$ primer & Allele $\mathrm{HEX}^{\mathrm{c}}$ primer & Common primer & Polymorphism $^{\mathrm{d}}$ \\
\hline KS11 & $153,797,365$ & $\begin{array}{l}\text { GCAGAGCCTCAGGTCCTC } \\
\text { AGA }\end{array}$ & $\begin{array}{l}\text { CAGAGCCTCAGGTCCTCA } \\
\text { GC }\end{array}$ & $\begin{array}{l}\text { CTGCGGAATGGACAGGTG } \\
\text { AGCTT }\end{array}$ & $\mathrm{A} / \mathrm{C}$ \\
\hline KS4 & $136,581,449$ & $\begin{array}{l}\text { GTTCTCCCAGCACTGAGC } \\
\text { AAGT }\end{array}$ & $\begin{array}{l}\text { CTCCCAGCACTGAGC } \\
\text { AAGC }\end{array}$ & $\begin{array}{l}\text { CTTTCGGATCAACAGAAT } \\
\text { TTGCAGCTTAT }\end{array}$ & $\mathrm{A} / \mathrm{G}$ \\
\hline KS3 & $134,269,830$ & $\begin{array}{l}\text { ACGTAATAATGATCCAAA } \\
\text { AAATCAACAACG }\end{array}$ & $\begin{array}{l}\text { ATAACGTAATAATGATCC } \\
\text { AAAAAATCAACAACT }\end{array}$ & $\begin{array}{l}\text { GATGGCTGCATCTCCCAT } \\
\text { AGGAATA }\end{array}$ & $\mathrm{G} / \mathrm{T}$ \\
\hline $\mathrm{KS} 10$ & $150,740,579$ & $\begin{array}{l}\text { GCCTTGATATGTACTTGT } \\
\text { CTACA }\end{array}$ & $\begin{array}{l}\text { GCCTTGATATGTACTTGT } \\
\text { CTACC }\end{array}$ & $\begin{array}{l}\text { ACAATCACTGGTGGTATG } \\
\text { GGCCAT }\end{array}$ & $\mathrm{A} / \mathrm{C}$ \\
\hline KS20 & $146,007,753$ & $\begin{array}{l}\text { GGAGCTGGCTTTGCTGCT } \\
\text { GTT }\end{array}$ & $\begin{array}{l}\text { GGAGCTGGCTTTGCTGCT } \\
\text { GTG }\end{array}$ & $\begin{array}{l}\text { GACGAGGACGACCAC } \\
\text { CGGTA }\end{array}$ & TGT/- \\
\hline KS27 & $152,677,635$ & GCCCACAGGCGTCGGGC & GCCCACAGGCGTCGGGG & $\begin{array}{l}\text { AGTTGGCGCCGATGAGGA } \\
\text { GGTT }\end{array}$ & $\mathrm{C} / \mathrm{G}$ \\
\hline $\mathrm{KS} 28$ & $151,638,826$ & $\begin{array}{l}\text { GAATTCACTTGTGATGTT } \\
\text { TTTTTTGTGG }\end{array}$ & $\begin{array}{l}\text { CTGAATTCACTTGTGATG } \\
\text { TTTTTTTTGTGA }\end{array}$ & $\begin{array}{l}\text { ACTAGACACAGGAATGCA } \\
\text { AYGGCAA }\end{array}$ & $\mathrm{C} / \mathrm{T}$ \\
\hline KS19 & $146,364,681$ & $\begin{array}{l}\text { GAGCATATTTGAATTGTA } \\
\text { AGGTGATACC }\end{array}$ & $\begin{array}{l}\text { CGAGCATATTTGAATTGT } \\
\text { AAGGTGATACT }\end{array}$ & $\begin{array}{l}\text { CCGCCACAAGCTWATG } \\
\text { TTAATAGACAATA }\end{array}$ & G/A \\
\hline KS30 & $141,338,119$ & $\begin{array}{l}\text { AACAGCCAAAGCAACTAA } \\
\text { AGCAAACTA }\end{array}$ & $\begin{array}{l}\text { CAGCCAAAGCAACTAAAG } \\
\text { CAAACTG }\end{array}$ & $\begin{array}{l}\text { GTTGTTTGTACTAGKCGG } \\
\text { GCATCAATT }\end{array}$ & $\mathrm{T} / \mathrm{C}$ \\
\hline $\operatorname{ctg} 358-01$ & $152,257,137$ & $\begin{array}{l}\text { CGGGAAAGCTTATACAGC } \\
\text { TCTCA }\end{array}$ & $\begin{array}{l}\text { CGGGAAAGCTTATACAGC } \\
\text { TCTCG }\end{array}$ & $\begin{array}{l}\text { GCCAGCCTCTTGTGAACG } \\
\text { CTATTAT }\end{array}$ & $\mathrm{T} / \mathrm{C}$ \\
\hline $\operatorname{ctg} 358-37$ & $151,680,633$ & $\begin{array}{l}\text { CGACTTCCCCATTAACCA } \\
\text { TCCGA }\end{array}$ & $\begin{array}{l}\text { GACTTCCCCATTAACCAT } \\
\text { CCGG }\end{array}$ & $\begin{array}{l}\text { CGGTCCCGAATTTACAGT } \\
\text { CGAACAA }\end{array}$ & TTT/- \\
\hline $\operatorname{ctg} 358-05$ & $151,668,694$ & $\begin{array}{l}\text { ATCTAATAGAGTTCTTGG } \\
\text { AAATCTACGATA }\end{array}$ & $\begin{array}{l}\text { CTAATAGAGTTCTTGGAA } \\
\text { ATCTACGATG }\end{array}$ & $\begin{array}{l}\text { CAGAAACAGAACATTGTT } \\
\text { AGTGCAAGACTA }\end{array}$ & $\mathrm{A} / \mathrm{G}$ \\
\hline $\operatorname{ctg} 358-14$ & $151,446,446$ & GCCGCACGAGGACGGGTC & GCCGCACGAGGACGGGTT & $\begin{array}{l}\text { GAGCTTAAGCGCGTCAGT } \\
\text { CCAAATT }\end{array}$ & G/A \\
\hline $\operatorname{ctg} 359-01$ & $153,687,938$ & $\begin{array}{l}\text { TCCCAGGCCACCAAAATG } \\
\text { GTC }\end{array}$ & $\begin{array}{l}\text { AATTTCCCAGGCCACCAA } \\
\text { AATGGTT }\end{array}$ & $\begin{array}{l}\text { CCCAAGGATTTGAGAAAG } \\
\text { GGTTTTGAAAA }\end{array}$ & $\mathrm{C} / \mathrm{T}$ \\
\hline
\end{tabular}

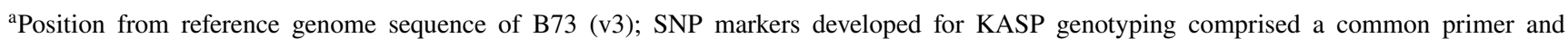
two allele-specific primers which were labeled with two different fluorophores: $\mathrm{FAM}^{\mathrm{b}}$ and $\mathrm{HEX}^{\mathrm{c}}$, respectively; ${ }^{\mathrm{d}}$ polymorphism between the Z033E0056 and Z032E0081 alleles which can be distinguished by the corresponding KASP marker 
Table 2 Information of SSR and other markers

\begin{tabular}{lllll}
\hline Primer name & ${\text { Position }(\mathrm{v} 3)^{\mathrm{a}}}^{\mathrm{a}}$ & Marker type $^{\mathrm{b}}$ & Forward & Reverse \\
\hline umc2199 $^{\mathrm{c}}$ & $149,146,480$ & SSR & ACCGAGTTAAGATTACATCACGCC & TGTTTCCCCTAATAAAGCAAATGAA \\
umc2210 $^{\mathrm{c}}$ & $152,001,123$ & SSR & GATGCTACCATTTCAGTGAGCGAT & AGCGGGTCGATCTTTCTCTTAGTT \\
umc1287 $^{\mathrm{c}}$ & $156,640,498$ & SSR & ATGGGATGATCAGTCGTTTCAGTC & AGAAGGAGGCCCACTACGAGAG \\
$\operatorname{ctg} 358-18^{\mathrm{d}}$ & $151,442,614$ & Size & AACATCCAGGGCGAGTGTCT & AGCATCGGTTAGGGTTTCCA \\
$\operatorname{ctg} 358-20^{\mathrm{d}}$ & $151,528,279$ & Size & CAGCGTCCAACAACACATCC & ACGACCTCCGACTCCTACCC \\
$\operatorname{ctg} 358-33^{\mathrm{d}}$ & $152,129,338$ & Size & GCTTGCCTGTTCATCCTGGT & TCGCTCTTCCTTGACGCTTT \\
$\operatorname{ctg} 358-32^{\mathrm{d}}$ & $152,128,452$ & Sequence & CAACCTCTCCTCCCTCCAGA & CAGCGTTCCCTTCCAGTGA \\
P1 $^{\mathrm{e}}$ & $152,243,515$ & Sequence & AAGCACTGTATGTCGGACGG & CCAGAGAGACGGTTCCCATC \\
P6 $^{\mathrm{e}}$ & $152,240,171$ & Sequence & GACGGAGATGCAGATCGTTA & ATCCTCAAAACAAGTGCCCG \\
\hline
\end{tabular}

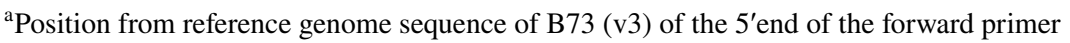

${ }^{\mathrm{b}}$ SSR- simple sequence repeat; Size- alleles were distinguished based on their sizes assessed when run on a $1 \%$ agarose gel; sequence-alleles were distinguished based on direct sequencing of PCR products

${ }^{\mathrm{c}}$ These primers are from MaizeGDB (http://www.maizegdb.org/)

${ }^{\mathrm{d}}$ These primers are from Chung et al. (2010)

${ }^{\mathrm{e}}$ The annealing temperatures of $\mathrm{P} 1$ and $\mathrm{P} 6$ are $68^{\circ} \mathrm{C}$ and $65^{\circ} \mathrm{C}$, respectively

by running the products on a conventional $4 \%$ agarose gel. The Z033E0056 and Z032E0081 products of three markers, ctg358-18, ctg358-20, and ctg358-33, that had previously been described as CAPS (cleaved amplified polymorphic site) markers in Chung et al. (2010) could be distinguished based on size alone when run $1 \%$ agarose gels. Finally, PCR products from two primers pairs we designed, P1 and P6, and ctg358-32 in Chung et al. (2010) were directly sequenced to distinguish the Z033E0056 and Z032E0081 alleles. Positions of all markers used in this paper are based on the reference genome sequence of B73 (v3).

\section{Genotyping}

PCR reactions for SSR genotyping (umc2199, umc2210, umc1287) were performed in total volumes of $15 \mu \mathrm{l}$, including $1.5 \mu \mathrm{l} 10 \times$ buffer (DreamTaq Green buffer, Thermo Scientific, Cat\# EP0713), $0.3 \mu 10 \mathrm{mM}$ dNTPs (Promega Corporation, Cat\# U151B), $0.2 \mu \mathrm{l}$ forward and reverse primers, $0.1 \mu \mathrm{l}$ Taq DNA polymerase (DreamTaq Green DNA Polymerase, Thermo Scientific, Cat\# EP0713), $1 \mu \mathrm{l} 50 \mathrm{ng} / \mu \mathrm{l}$ DNA, and $11.7 \mu \mathrm{l}$ distilled $\mathrm{H}_{2} \mathrm{O}$.

Touchdown PCR was employed for the detection of SSR markers. The PCR procedure was as follows: $95^{\circ} \mathrm{C}$ for $5 \mathrm{~min}, 10$ cycles of $95^{\circ} \mathrm{C}$ for $30 \mathrm{~s}, 67-57^{\circ} \mathrm{C}$ for $30 \mathrm{~s}\left(1^{\circ} \mathrm{C}\right.$ decrease per cycle) and $72^{\circ} \mathrm{C}$ for $40 \mathrm{~s}, 35$ cycles of $95^{\circ} \mathrm{C}$ for $30 \mathrm{~s}, 57^{\circ} \mathrm{C}$ for $30 \mathrm{~s}$, and $72^{\circ} \mathrm{C}$ for $40 \mathrm{~s}$, with the final extension at $72^{\circ} \mathrm{C}$ for $10 \mathrm{~min}$. The PCR products of SSR markers were distinguished on $4 \%$ agarose gels.

PCR reaction conditions for $\operatorname{ctg} 358-18, \operatorname{ctg} 358-20$, ctg358-33, and $\operatorname{ctg} 358-32$ were the same as that of SSR markers while the PCR program used was the same as reported in Chung et al. (2010). The PCR products of ctg358-18, ctg358-20, and $\operatorname{ctg} 358-33$ were distinguished on $1 \%$ agarose gels, while PCR product of $\operatorname{ctg} 358-32$ was cleaned and sequenced to get polymorphic information between Z033E0056 and Z032E0081.

The KASP assays were run on 384-well plates and were set up in a total volume of $5.07 \mu \mathrm{l}$, consisting of $2.5 \mu \mathrm{l} 20 \mathrm{ng} / \mu \mathrm{l}$ genomic DNA, $2.5 \mu \mathrm{l} 2 \times$ KASP Master mix (Cat\# KBS-1016-017), and 0.07 $\mu 1$ KASP Assay mix (KASP primers). Touchdown PCR was used for as follows: $94^{\circ} \mathrm{C}$ for $15 \mathrm{~min}, 10$ cycles of $94{ }^{\circ} \mathrm{C}$ for $20 \mathrm{~s}$, $61-55{ }^{\circ} \mathrm{C}$ or $1 \mathrm{~min}\left(0.6^{\circ} \mathrm{C}\right.$ decrease per cycle), 25 cycles of $94{ }^{\circ} \mathrm{C}$ for $20 \mathrm{~s}$, and $55^{\circ} \mathrm{C}$ for $1 \mathrm{~min}$. After PCR, endpoint genotyping on a LightCycler 480 (Roche Molecular Systems, Inc.) was used to analyze the fluorescence of different genotypes of each KASP marker. Fluorescence can be clustered into three types: allele Z033E0056 type, heterozygous, or allele Z032E0081 type.

Markers P1 and P6 were amplified in $25 \mu \mathrm{l}$ carrying $5 \mu 15 \times$ Q5 reaction buffer (New England BioLabs Inc., Cat\# M0491S), $0.5 \mu 110 \mathrm{mM}$ dNTPs (Promega Corporation, Cat\# U151B), $1.25 \mu 1$ forward and reverse primers, $0.25 \mu \mathrm{l}$ Q5 high-fidelity DNA polymerase (New England BioLabs Inc., Cat\# M0491S), $1 \mu 150 \mathrm{ng} / \mu \mathrm{l}$ DNA, and $15.75 \mu \mathrm{l}$ distilled $\mathrm{H}_{2} \mathrm{O}$. PCR program was applied as follows: $98^{\circ} \mathrm{C}$ for $30 \mathrm{~s}, 30$ cycles of $98^{\circ} \mathrm{C}$ for $10 \mathrm{~s}, 68 / 65^{\circ} \mathrm{C}$ for $30 \mathrm{~s}$, and $72^{\circ} \mathrm{C}$ for $30 \mathrm{~s}$, with the final extension at $72^{\circ} \mathrm{C}$ for $2 \mathrm{~min}$. PCR products were cleaned using QIAquick ${ }^{\circledR}$ Gel Extraction Kit (Cat\# 28704) and sequenced in Genomic Sciences Laboratory (North Carolina State University). Sequences of Z033E0056 and Z032E0081 were aligned to get polymorphism information. 


\section{Data analysis and QTL mapping}

Statistical analysis was performed using SPSS 13.0 (SPSS, Chicago, USA). The genetic positions of the markers were assigned using the NAM genetic map (McMullen et al. 2009; Olukolu et al. 2014), and the physical positions were based on the B73 version 3 genome assembly (http://www. maizegdb.org/). QTL mapping was performed using Windows QTL Cartographer software v2.5 based on composite interval mapping (CIM, Silva et al. 2012). The walk speed was $1.0 \mathrm{cM}$. 1000 permutation tests at a significant level of 0.05 were performed to determine likelihood of odds ratio (LOD) threshold value for each trait.

\section{Results}

\section{Dominance of the resistance allele at $Q g l s 8$}

From our previous study (Lennon et al. 2016), we demonstrated that the two B73 NILs Z032E0081 and Z033E0056 carry introgressions from different teosinte accessions with different effects at $Q g l s 8$ (Fig. 1). The allele from Z032E0081 conferred GLS resistance, while that from Z033E0056 conferred GLS susceptibility relative to the B73 allele. The effects of the Z032E0081 and Z033E0056 alleles measured in the Lennon et al. (2016) study were, respectively, 0.51 and -0.61 on the $1-9$ scale employed. We produced $F_{1}$ plants from reciprocal crosses of Z032E0081 and Z033E0056 and assessed them for GLS resistance relative to each of its parents in replicated field trials in Andrews NC in the summer of 2016. The Z032E0081 and Z033E0056 parents had average scores of 6.25 and 4.13 , respectively, while the $F_{1}$ had an average score of 5.88, indicating that the resistance allele is largely dominant at $Q g l s 8$.

\section{Validation of $Q g l s 8$}

Before fine mapping of $Q g l s 8$, we needed to verify that this QTL segregated and was detectable in an $F_{2}$ population derived from Z032E0081 (resistant) and Z033E0056 (susceptible). Using two markers PZA03612-2 and umc1287 that were predicted to flank $Q g l s 8$ based on our previous work (Lennon et al. 2016), we screened $1273 F_{2}$ plants and identified 279 individuals recombinant between these markers. These plants were selfed to produce $279 F_{2: 3}$ families (see Fig. 2). 74 of these $279 F_{2: 3}$ families were scored for GLS resistance in Andrews and Blacksburg, respectively, in the summer of 2015. The families were genotyped with 13 markers (PZA03612-2, KS3, KS4, KS30, PZA00429-1, KS20, KS19, umc2199, KS10, KS28, KS27, KS11, umc1287) dispersed evenly in the $\sim 15 \mathrm{cM}$ region.
After analysis of the data from Andrews, a QTL associated with GLS resistance was identified in the $Q g l s 8$ region with a peak at marker KS28 (see Ad2015 result in Fig. 3; Table S1). But there was no obvious QTL peak identified after analysis using phenotypic data from Blacksburg (VA2015 result in Fig. 3; Table S1). We concluded that the chromosome region defined by PZA03612-2 and umc1287 did harbor $Q g l s 8$ but that the QTL appeared to be environment-specific.

\section{Fine mapping of the GLS resistance QTL}

142 independently derived homozygous recombinant plants were identified from the 279 recombinant $F_{2: 3}$ families and genotyped with the markers PZA03612-2, KS3, KS4, KS30, PZA00429-1, KS20, KS19, umc2199, KS10, KS28, KS27, KS11, umc1287, in order to saturate the $\sim 15 \mathrm{cM}$ Qgls8 region (Fig. 4). 142 independent homozygous recombinant $F_{4}$ lines were derived from these plants and were assessed for GLS resistance in randomized replicated field trials in Andrews NC and Blacksburg VA during the summer of 2016.

Similar to our observations from the analysis of the $F_{2: 3}$ populations, the effect of $Q g l s 8$ was not apparent in the data from Blacksburg, VA (compare Ad2016 and VA2016 results in Fig. 3), in fact even the phenotypes of the parental lines were not consistently distinct in Blacksburg VA (scores of Z032E0081 and Z033E0056 were 6.4 and 6, respectively, in Blacksburg compared with 6.3 and 4.1 in Andrews NC). This confirmed our conclusion that $Q g l s 8$ was environment-specific, and therefore only phenotypic data from Andrews $\mathrm{NC}$ were used in the subsequent analyses. Using these data we were able to 'Mendelize' the trait; in other words, we were able to designate each line as either resistant or susceptible based on whether the phenotype was significantly different to the susceptible parent Z033E0056 (Fig. 4a). The 142 lines were divided into 23 classes, A through $\mathrm{W}$, based on their recombinant types. Classes $\mathrm{C}$ and $\mathrm{N}$ were further sub-divided based on the fact that in each of these classes resistant and susceptible lines were found (Fig. 4a).

Referring to Fig. 4a, recombinant classes A and B are both resistant, class $\mathrm{C}$ is split into class $\mathrm{C}-1$ (resistant) and class $\mathrm{C}-2$ (susceptible), and classes D through $\mathrm{M}$ are susceptible. This implies that the causal gene underlying $Q g l s 8$ is located in the region flanked by markers $\mathrm{KS} 28$ and $\mathrm{KS} 27$, where the $\mathrm{C}$ class recombination events were determined to have occurred. This conclusion was confirmed by the inspection of classes $\mathrm{N}$ through $\mathrm{W}$. The recombination events defining class $\mathrm{N}$ also occur in the KS28-KS27 interval and again this class can be sub-divided into both resistant (class N-2) and susceptible (N-1) lines (Fig. 4a). 


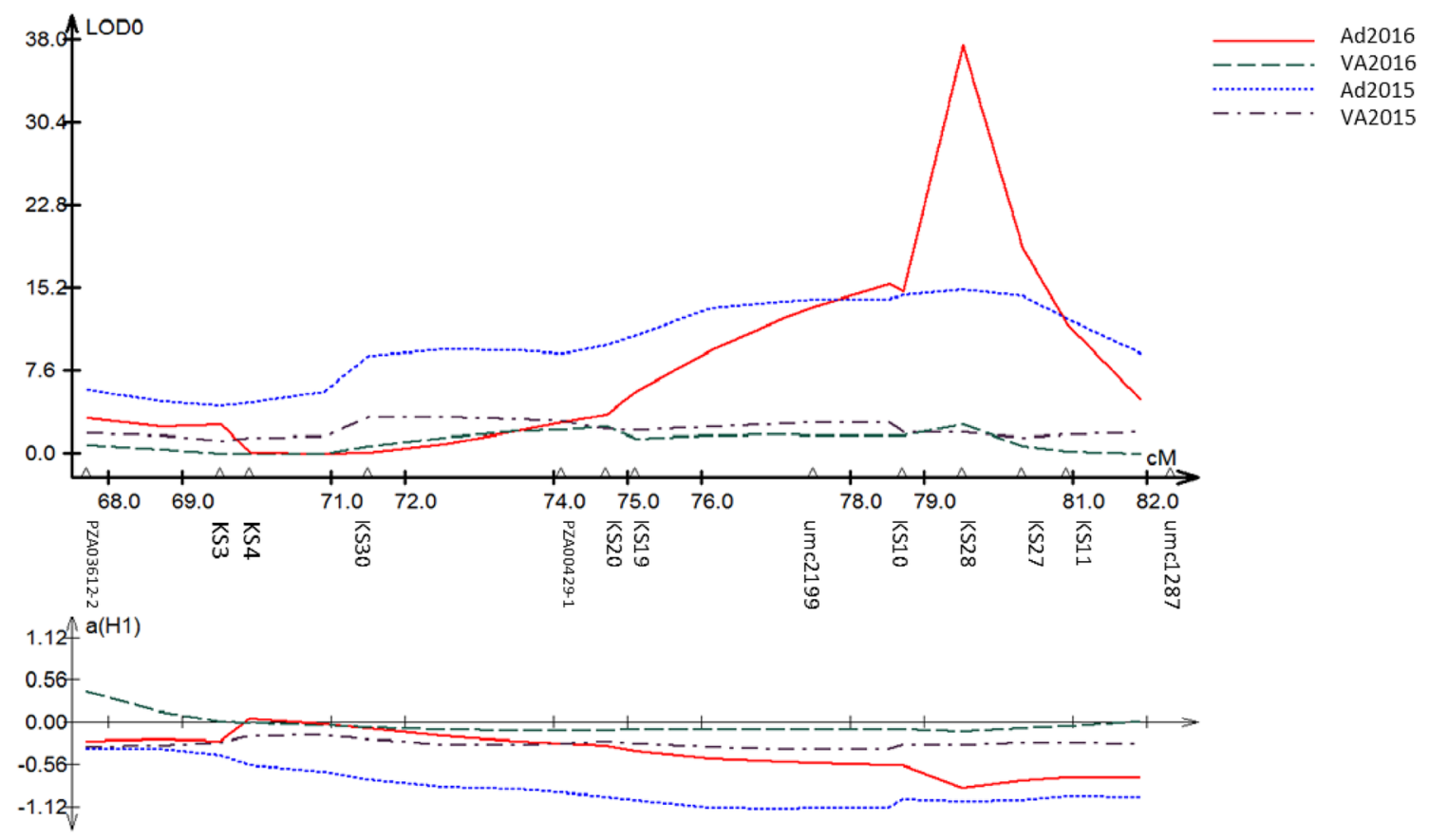

Fig. 3 Validation of $Q g l s 8$ using 74 recombinant $F_{2: 3}$ families in 2015 with one replicate in each location and 142 homozygous recombinant $F_{4}$ lines in 2016 with two replicates in each location. Each year

Classes $\mathrm{O}$ through $\mathrm{W}$ are all resistant, again consistent with the positioning of $Q g l s 8$ in the KS28-KS27 interval.

We developed or identified eight markers ( $\operatorname{ctg} 358$ 05, $\operatorname{ctg} 358-37, \quad u m c 2210, \operatorname{ctg} 358-32, \operatorname{ctg} 358-33, \quad \mathrm{P} 6$, $\mathrm{P} 1$, ctg358-01) located between KS28 and KS27 and used them to screen all the $\mathrm{C}-1, \mathrm{C}-2, \mathrm{~N}-1$, and $\mathrm{N}-2$ class lines. With the addition of new markers, the $\mathrm{C}-2$ and $\mathrm{N}-1$ classes could be further sub-divided by recombination location (Fig. 4b). Inspection of these data (Fig. 4b) unequivocally places $Q g l s 8$ in the $\sim 130 \mathrm{~kb}$ region defined by $\operatorname{ctg} 358-32$ and $\operatorname{ctg} 358-01$. According to B73 reference genome sequence (v3), the $\sim 130 \mathrm{~kb}$ region harbored five genes: GRMZM2G360219, GRMZM2G060886, GRMZM2G316907, GRMZM2G316904, and GRMZM2G014089 (Fig. 4c). Table 3 shows the information of five candidate genes. Both GRMZM2G360219 and GRMZM2G316907 were annotated as receptor-like protein kinase. GRMZM2G014089 was predicted as ABC transporter ATP-binding protein.

\section{Discussion}

GLS is a very serious foliar disease of maize. Yield losses could be up to $80-100 \%$ because of lodging caused by stalk deterioration during severe epidemics which impeded harvesting mechanically (Latterell and Rossi 1983; Danson the two locations used were Andrews, NC (noted above as Ad) and Blacksburg, VA (VA)

et al. 2008). Cultivation of varieties resistant to GLS has been considered as an effective method to control GLS (Danson et al. 2008; Zhang et al. 2012). Numerous studies investigating the genetic basis of GLS resistance have concluded that resistance is based on numerous loci each with a small effect; in other words, GLS resistance in corn is inherited as a typical quantitative trait.

Here we report the fine mapping of a GLS QTL, Qgls 8 located in Bin 8.06 to a $\sim 130 \mathrm{~kb}$ region defined by the markers $\operatorname{ctg} 358-32$ and $\operatorname{ctg} 358-01 \quad(152,128,452$ $152,257,137 \mathrm{bp}$ on the B73 v3 genome). We set up the mapping population used in this study so that previously identified resistance and susceptibility alleles (both relative to the B73 allele) were segregating against each other. This had the intended effect of increasing the perceived effect at $Q g l s 8$ and allowed us to categorize lines as either resistant or susceptible. The effect observed at $Q g l s 8$ in the $F_{4}$ populations assessed at Andrews was -0.85 on our 1-9 scale (Table S1), compared to effects of 0.51 and -0.61 observed previously (Lennon et al. 2016) for the resistance and susceptibility alleles segregating against the B73 allele, respectively. While comparison of effects across environments and years is not entirely legitimate due to differences in disease pressure, scoring date etc., this does suggest that by producing a population in which these alleles segregated against each other, we were able to somewhat increase the contrast at $Q g l s 8$. 


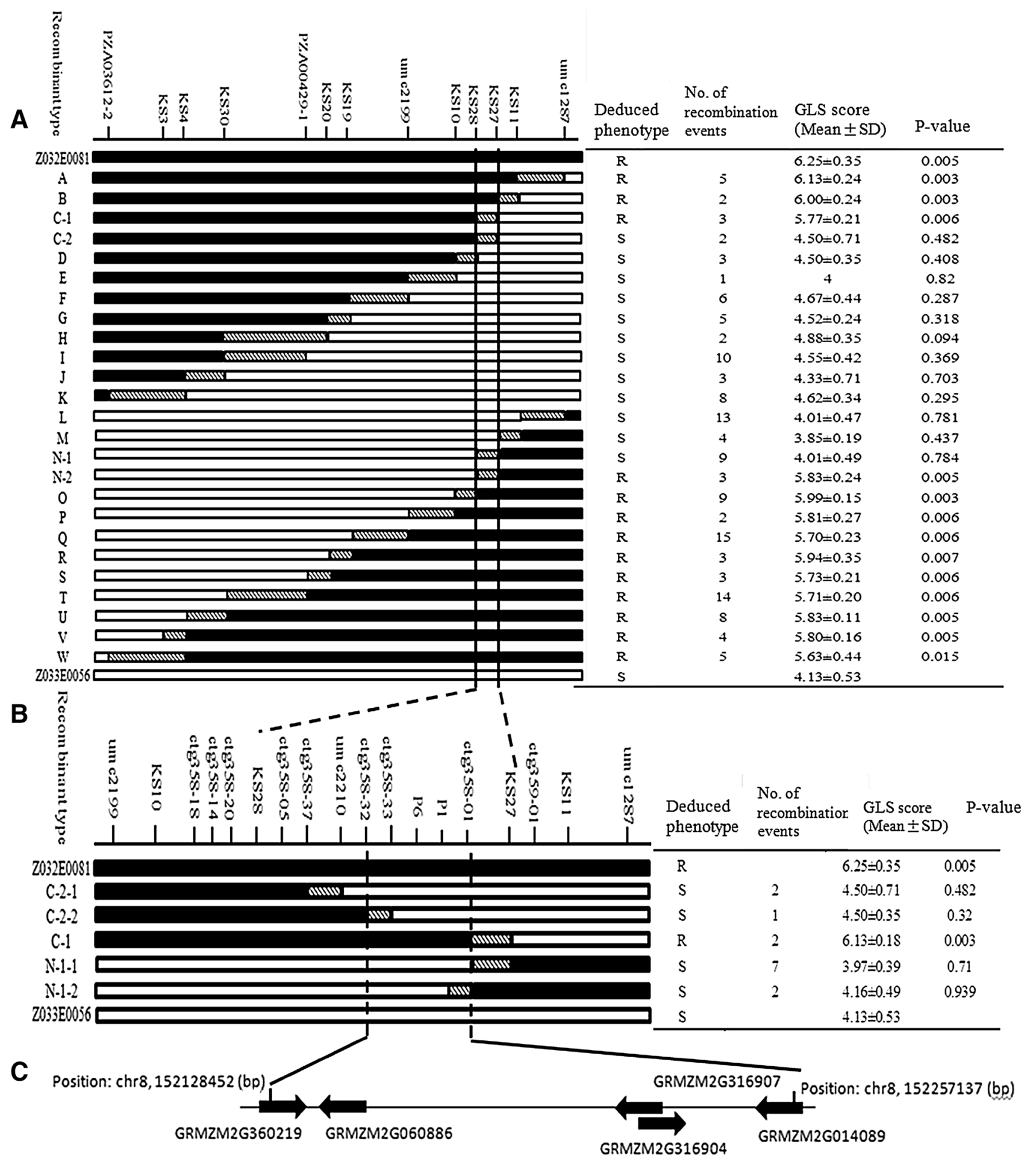

Fig. 4 Fine mapping of $Q g l s 8$ using selected homozygous recombinant $F_{4}$ lines. Black rectangle represents homozygous genotypes of Z032E0081 (resistant); White rectangle represents homozygous genotypes of Z033E0056 (susceptible); Gray rectangle represents the region in which recombination occurred; Recombinant types C-2-1 (b) and C-2-2 (b) are both from the recombinant C-2 (a); Recombinant types N-1-1 (b) and N-1-2 (b) are both from the recombinant
$\mathrm{N}-1$ (a); The $P$ value is the likelihood that the resistance of each line is not different to that of the susceptible parent Z033E0056; The position showed here is from reference genome sequence of B73 (v3) (c); black arrows in different directions represent different genes (c); the left and right vertical lines represent the positions of the markers ctg358-32 and ctg358-01, respectively 
Table 3 Information of candidate genes underlying the $\sim 130 \mathrm{~kb}$ region of $Q g l s 8$

\begin{tabular}{|c|c|c|}
\hline Gene ID & Start-end (v3) ${ }^{\mathrm{a}}$ & Function annotation \\
\hline GRMZM2G360219 & 152127054.0 .152130466 & Receptor-like protein kinase 2 precursor \\
\hline GRMZM2G060886 & 152130931.0 .152135975 & $\begin{array}{l}\text { CPuORF25-conserved peptide uORF- } \\
\text { containing transcript expressed }\end{array}$ \\
\hline GRMZM2G316907 & 152240805.0 .152244210 & Receptor-like protein kinase 2 precursor \\
\hline GRMZM2G316904 & 152241660.0 .152244983 & Uncharacterized protein \\
\hline GRMZM2G014089 & 152253211.0 .152257798 & ABC (ATP-binding cassette) transporter \\
\hline
\end{tabular}

${ }^{\text {a }}$ Position of the reference genome sequence of B73 (v3)
Several studies have identified GLS resistance QTL in the same region. A QTL for GLS resistance in the same region on chromosome 8 identified by Saghai Maroof et al. (1996) explained $7.7-11.0 \%$ of phenotypic variance using $F_{2}$ and $F_{2: 3}$ populations derived from the cross between B73 and Val4. A consensus GLS resistance QTL was detected in bin 8.06 using meta-analysis based on data from 5 publications (Shi et al. 2007). Benson et al. (2015), using the extremely powerful 5000-line NAM population (McMullen et al. 2009), found one SNP (PZA03651.1) in bin 8.06 associated GLS resistance, about $5 \mathrm{Mb}$ from the $Q g l s 8$ region defined here.

It should be noted that flowering time has been reported to have an effect on perceived resistance levels to GLS (e.g., Zwonitzer et al. 2010). While we did not score flowering time in this study, previous studies using the original population in which $Q g l s 8$ was identified have reported flowering time QTL at around $67 \mathrm{cM}$ on chromosome 8 (NAM map coordinates) and have identified ZCN8, located at $123,030,387-123,032,175 \mathrm{bp}$ (B73v3 assembly) as a possible causative gene (Lennon et al. 2016; Liu et al. 2016). This would place the flowering time locus as $\sim 9 \mathrm{cM}$ and $\sim 30 \mathrm{Mbp}$ from $Q g l s 8$, making it unlikely that $Q g l s 8$ was influencing flowering time.

Resistance genes for several other diseases map near Qgls8. Chung et al. (2010) reported that $q N L B 8.06_{D K 888}$, a QTL for NLB resistance was found near $Q g l s 8$. The Ht2 and $H t n l$ genes for resistance to NLB are also found in this region (Zaitlin et al. 1992; Simcox and Bennetzen 1993). Htnl was recently shown to encode a wall-associated receptor-like kinase (Hurni et al. 2015). According to our data, Htnl is $\sim 600 \mathrm{~kb}$ upstream of $Q g l s 8$, which partially overlaps $q N L B 8.06_{D K 888}$.

No other GLS resistance QTL have been as precisely defined as $Q g l s 8$. Zhang et al. (2012) identified two major QTL, $q R g l s 1$ and $q R g l s 2$ for GLS resistance on chromosomes 8 and 5, respectively, and finely mapped $q R g l s 1$ to an interval of 1.4 Mb. In the subsequent study, Xu et al. (2014) narrowed the region of the second major QTL $-q R g l s 2$ from an initial $\sim 110 \mathrm{Mb}$ to an interval of $\sim 1 \mathrm{Mb}$ which harbored 15 predicted genes. The NAM study performed by Benson et al. (2015) mapped two GLS resistance QTL on chromosome 1 to regions of 6.5 and $5.2 \mathrm{Mb}$. We have defined a relatively small $\sim 130 \mathrm{~kb}$ region encompassing five predicted genes (Table 3). Of these five genes, three are similar to genes with defined roles in disease resistance: Both GRMZM2G360219 and GRMZM2G316907 encode receptor-like protein kinases. Proteins of this type function as pattern-recognition receptors (PRRs) involved in sensing microbe-associated molecular patterns (MAMP) and inducing MAMP-triggered immunity (MTI) (Newman et al. 2013). GRMZM2G014089 is predicted to be an ABC transporter ATP-binding protein. A protein of this type, LR34, regulates resistance to several fungal diseases in wheat (Krattinger et al. 2009). We continue to screen new recombinants and insertional mutants to definitively identify the causal gene at $Q g l s 8$. It should be noted that the $\sim 130 \mathrm{~kb}$ region and the genes within it are all defined based on the sequenced B73 genome. However, in this study, both the resistance and the susceptibility alleles derive from teosinte, Z. mays ssp parviglumis. Gene complements are known to vary extensively between maize genotypes. For instance, comparisons of the B73 and PH207 maize genomes suggest that more than 2500 genes (about $8 \%$ of the total number) occur in only one or other of the genomes (Hirsch et al. 2016). It is therefore quite possible that the actual causal gene for $Q g l s 8$ may not be any of the genes listed in Table 3. If that is the case, the $Q g l s 8$ regions from the lines Z032E0081 and Z033E0056 will need to be sequenced to determine the identity of the causal gene.

In this study, we assessed GLS resistance in two different environments: Andrews, NC and Blacksburg, VA. But the effect of $Q g l s 8$ was not apparent in Blacksburg, VA in the original lines and in $F_{2: 3}$ families and $F_{4}$ lines (Fig. 3). In our previous study in which $Q g l s 8$ was identified, only the Andrews, NC environment was used (Lennon et al. 2016). Quantitative traits in general are well known for often having environment-specific effects (e.g., Snape et al. 2007). Environment-specific QTL for GLS have been noted previously (Bubeck et al. 1993; Gordon et al. 2004; Balint-Kurti et al. 2008). The disease pressure in Andrews was much higher, which meant the disease appeared earlier and progressed more quickly. We only used artificial inoculation at the Blacksburg site. The Andrews site was also 
more prone to morning mists, which are conducive to GLS development (Beckman and Payne 1982). The environment-specificity may have been due to any of these factors, a combination of them or to factors we have not considered. As we identify the causal gene, it will be extremely interesting to determine the reason for its conditional effects.

Author contribution statement XZ, QY, and PBK planned the research; XZ, ER, WT, QY, and PBK executed the field trials; XZ and QY performed the genotyping and developed the molecular markers; $\mathrm{XZ}$ and QY performed the analysis; XZ and PBK wrote the manuscript; and QY, $\mathrm{ER}$, and WT edited the manuscript.

Acknowledgements QY is supported by NSF Grant \#1127076, "Genetic and Histological Dissection of Phenotypic Variation in Quantitative Resistance to Maize Diseases"; XY is supported by a China Scholarship Council Fellowship. We are very grateful to Jose Santa-Cruz Hidalgo, Julie Taylor, and Monsanto Inc. for planting and managing our experiments in Andrews NC.

\section{Compliance with ethical standards}

Conflict of interest The authors declare that they have no conflict of interest.

Research involving animal and human rights This article does not contain any studies with human participants or animals performed by any of the authors.

\section{References}

Asea G, Vivek BS, Lipps PE, Pratt RC (2012) Genetic gain and cost efficiency of marker-assisted selection of maize for improved resistance to multiple foliar pathogens. Mol Breed 29:515-527

Balint-Kurti PJ, Wisser R, Zwonitzer JC (2008) Use of an advanced intercross line population for precise mapping of quantitative trait loci for gray leaf spot resistance in maize. Crop Sci 48:1696-1704

Beckman PM, Payne GA (1982) External growth, penetration, and development of Cercospora zeae-maydis in corn leaves. Phytopathology 72:810-815

Benson JM, Poland JA, Benson BM, Stromberg EL, Nelson RJ (2015) Resistance to gray leaf spot of maize: genetic architecture and mechanisms elucidated through nested association mapping and near-isogenic line analysis. PLoS Genet 11:e1005045

Berger DK, Carstens M, Korsman JN, Middleton F, Kloppers FJ, Tongoona P, Myburg AA (2014) Mapping QTL conferring resistance in maize to gray leaf spot disease caused by Cercospora zeina. BMC Genet 15:60

Bubeck DM, Goodman MM, Beavis WD, Grant D (1993) Quantitative trait loci controlling resistance to gray leaf spot. Crop Sci 33:838-847

Chung CL, Jamann T, Longfellow J, Nelson R (2010) Characterization and fine-mapping of a resistance locus for northern leaf blight in maize bin 8.06. Theor Appl Genet 121:205-227

Chung CL, Poland J, Kump K, Benson J, Longfellow J, Walsh E, Balint-Kurti P, Nelson R (2011) Targeted discovery of quantitative trait loci for resistance to northern leaf blight and other diseases of maize. Theor Appl Genet 123:307-326

Clements MJ, Dudley JW, White DG (2000) Quantitative trait loci associated with resistance to gray leaf spot of corn. Phytopathology 90:1018-1025

Crous PW, Groenewald JZ, Groenewald M, Caldwell P, Braun U, Harrington TC (2006) Species of Cercospora associated with grey leaf spot of maize. Stud Mycol 55:189-197

Danson J, Lagat M, Kimani M, Kuria A (2008) Quantitative trait loci (QTLs) for resistance to gray leaf spot and common rust diseases of maize. Afr J Biotechnol 7:3247-3254

Davis GL, McMullen MD, Baysdorfer C, Musket T, Grant D, Staebell M, Xu G, Polacco M, Koster L, Melia-Hancock S, Houchins K, Chao S, Coe EH Jr (1999) A maize map standard with sequenced core markers, grass genome reference points and 932 expressed sequence tagged sites (ESTs) in a 1736-locus map. Genetics 152:1137-1172

Dhami NB, Kim SK, Paudel A, Shrestha J, Rija TR (2015) A review on threat of gray leaf spot disease of maize in Asia. J Maize Res Dev 1:71-85

Doebley JF, Iltis HH (1980) Taxonomy of Zea (gramineae).I. A subgeneric classification with key to taxa. Am J Bot 67: 982-993

Gordon SG, Bartsch M, Matthies I, Gevers HO, Lipps PE, Pratt RC (2004) Linkage of molecular markers to Cercospora zeae-maydis resistance in maize. Crop Sci 44:628-636

He C, Holme J, Anthony J (2014) SNP genotyping: the KASP assay. Methods Mol Biol 1145:75-86

Hirsch CN, Hirsch CD, Brohammer AB, Bowman MJ, Soifer I, Barad O, Shem-Tov D, Baruch K, Lu F, Hernandez AG, Fields CJ, Wright CL, Koehler K, Springer NM, Buckler E, Buell CR, de Leon N, Kaeppler SM, Childs KL, Mikel MA (2016) Draft assembly of elite inbred line $\mathrm{PH} 207$ provides insights into genomic and transcriptome diversity in maize. Plant Cell 28:2700-2714

Hurni S, Scheuermann D, Krattinger SG, Kessel B, Wicker T, Herren G, Fitze MN, Breen J, Presterl T, Ouzunova M, Keller B (2015) The maize disease resistance gene $H t n l$ against northern corn leaf blight encodes a wall-associated receptor-like kinase. Proc Natl Acad Sci USA 112:8780-8785

Iltis HH, Doebley JF (1980) Taxonomy of Zea (gramineae). II. Subspecific categories in the Zea mays complex and a generic synopsis. Am J Bot 67: 994-1004

Juliatti FC, Pedrosa MG, Silva HD, da Silva JVC (2009) Genetic mapping for resistance to gray leaf spot in maize. Euphytica 169:227-238

Kinyua ZM, Smith JJ, Kibata GN, Simons SA, Langat BC (2010) Status of grey leaf spot disease in Kenyan maize production ecosystems. Afr Crop Sci J 18:183-194

Korsman J, Meisel B, Kloppers FJ, Crampton BG, Berger DK (2012) Quantitative phenotyping of grey leaf spot disease in maize using real-time PCR. Eur J Plant Pathol 133:461-471

Krattinger SG, Lagudah ES, Spielmeyer W, Singh RP, Huerta-Espino J, McFadden H, Bossolini E, Selter LL, Keller B (2009) A putative $\mathrm{ABC}$ transporter confers durable resistance to multiple fungal pathogens in wheat. Science 323:1360-1363

Latterell FM, Rossi AE (1983) Gray leaf spot of corn: a disease on the move. Plant Dis 67:842-847

Lehmensiek A, Esterhuizen AM, van Staden D, Nelson SW, Retief AE (2001) Genetic mapping of gray leaf spot (GLS) resistance genes in maize. Theor Appl Genet 103:797-803

Lennon J, Krakowsky M, Goodman M, Flint-Garcia S, Balint-Kurti PJ (2016) Identification of alleles conferring resistance to gray leaf spot in maize derived from its wild progenitor species teosinte. Crop Sci 56:209-218

Lipps PE (1998) Gray leaf spot: a global threat to corn production. APSnet Features. doi:10.1094/APSnetFeature-1998-0598 
Liu KJ, Xu XD (2013) First report of gray leaf spot of maize caused by Cercospora zeina in China. Plant Dis 97:1656

Liu Z, Cook J, Melia-Hancock S, Guill K, Bottoms C, Garcia A, Ott O, Nelson R, Recker J, Balint-Kurti P, Larsson S, Lepak N, Buckler E, Trimble L, Tracy W, McMullen MD, Flint-Garcia SA (2016) Expanding maize genetic resources with predomestication alleles: maize-teosinte introgression populations. Plant Genome 9:1

Manandhar G, Ferrara GO, Tiwari TP, Baidya S, Bajracharya ASR, Khadge BR, Narro L (2011) Response of maize genotypes to gray leaf spot disease (Cercospora zeae-maydis) in the hills of Nepal. Agron J N 2:93-101

Matsuoka Y, Vigouroux Y, Goodman MM, Sanchez GJ, Buckler E, Doebley J (2002) A single domestication for maize shown by multilocus microsatellite genotyping. Proc Natl Acad Sci USA 99:6080-6084

McMullen MD, Kresovich S, Villeda HS, Bradbury P, Li H, Sun Q, Flint-Garcia S, Thornsberry J, Acharya C, Bottoms C, Brown P, Browne C, Eller M, Guill K, Harjes C, Kroon D, Lepak N, Mitchell SE, Peterson B, Pressoir G, Romero S, Oropeza Rosas M, Salvo S, Yates H, Hanson M, Jones E, Smith S, Glaubitz JC, Goodman M, Ware D, Holland JB, Buckler ES (2009) Genetic properties of the maize nested association mapping population. Science 325:737-740

Meisel B, Korsman J, Kloppers FJ, Berger DK (2009) Cercospora zeina is the causal agent of grey leaf spot disease of maize in southern Africa. Eur J Plant Pathol 124:577-583

Nega A, Lemessa F, Berecha G (2016) Distribution and importance of maize grey leaf spot Cercospora zeae-maydis (Tehon and Daniels) in south and southwest Ethiopia. J Plant Pathol Microbiol 7:362. doi:10.4172/2157-7471.1000362

Newman MA, Sundelin T, Nielsen JT, Erbs G (2013) MAMP (microbe-associated molecular pattern) triggered immunity in plants. Front Plant Sci 4:139

Okori P, Rubaihayo PR, Adipala E, Dixelius C (2004) Interactive effects of host, pathogen and mineral nutrition on grey leaf spot epidemics in Uganda. Eur J Plant Pathol 110:119-128

Olukolu BA, Wang GF, Vontimitta V, Venkata BP, Marla S, Ji J, Gachomo E, Chu K, Negeri A, Benson J, Nelson R, Bradbury P, Nielsen D, Holland JB, Balint-Kurti PJ, Johal G (2014) A genome-wide association study of the maize hypersensitive defense response identifies genes that cluster in related pathways. PLoS Genet 10:e1004562

Pozar G, Butruille D, Silva HD, McCuddin ZP, Penna JCV (2009) Mapping and validation of quantitative trait loci for resistance to Cercospora zeae-maydis infection in tropical maize (Zea mays L.). Theor Appl Genet 118:553-564

Rupe JC, Siegel MR, Hartman JR (1982) Influence of environment and plant maturity on gray leaf spot of corn caused by Cercospora zeae-maydis. Phytopathology 72:1587-1591
Saghai Maroof MA, Yue YG, Xiang ZX, Stromberg EL, Rufener GK (1996) Identification of quantitative trait loci controlling resistance to gray leaf spot disease in maize. Theor Appl Genet 93:539-546

Shi L, Li X, Hao Z, Xie C, Ji H, Lü X, Zhang S, Pan G (2007) Comparative QTL mapping of resistance to gray leaf spot in maize based on bioinformatics. Agr Sci China 6: 1411-1419

Silva da LCE, Wang S, Zeng ZB (2012) Composite interval mapping and multiple interval mapping: procedures and guidelines for using Windows QTL Cartographer. Methods Mol Biol $871: 75-119$

Simcox KD, Bennetzen JL (1993) The use of molecular markers to study Setosphaeria turcica resistance in maize. Phytopathology 83:1326-1330

Snape JW, Foulkes MJ, Simmonds J, Leverington M, Fish LJ, Wang Y, Ciavarrella M (2007) Dissecting gene $\times$ environmental effects on wheat yields via QTL and physiological analysis. Euphytica 154:401-408

Tehon LR, Daniels E (1925) Notes on the parasitic fungi of Illinois: II. Mycologia 17:240-249

Veiga AD, Von Pinho RG, Resende LV, Pinho ÉVDRV, Balestre M, Pereira LA (2012) Quantitative trait loci associated with resistance to gray leaf spot and grain yield in corn. Ciênc Agrotec 36: 31-38

Wallace JG, Larsson SJ, Buckler ES (2014) Entering the second century of maize quantitative genetics. Heredity 112:30-38

Ward JMJ, Stromberg EL, Nowell DC, Nutter FW Jr (1999) Gray leaf spot: a disease of global importance in maize production. Plant Dis 83:884-895

Xu L, Zhang Y, Shao S, Chen W, Tan J, Zhu M, Zhong T, Fan X, Xu M (2014) High-resolution mapping and characterization of qRgls2, a major quantitative trait locus involved in maize resistance to gray leaf spot. BMC Plant Biol 14:230

Yan W, Li Y, Song MX, Zhang KY, Sun MZ, Qu H, Li FH, Zhong XM, Zhu M, Du WL, Lü XL (2016) Meta-analysis and validation of QTL for resistance to gray leaf spot in maize. Acta Agron Sin 42:758-767

Zaitlin D, DeMars SJ, Gupta M (1992) Linkage of a second gene for NCLB resistance to molecular markers in maize. Maize Genet Coop Newsl 66: 69-70

Zhang Y, Xu L, Fan X, Tan J, Chen W, Xu M (2012) QTL mapping of resistance to gray leaf spot in maize. Theor Appl Genet 125:1797-1808

Zwonitzer JC, Coles ND, Krakowsky MD, Arellano C, Holland JB, McMullen MD, Pratt RC, Balint-Kurti PJ (2010) Mapping resistance quantitative trait loci for three foliar diseases in a maize recombinant inbred line population-evidence for multiple disease resistance? Phytopathology 100:72-79 